On Monday, November 10, the state officers and their deputies took charge of their respective offices in the new capitol building, and on January 11, 1858, the Seventh general assembly convened at the new state house and the state government was fully established in the city of Des Moines, within two miles of the junction of the Des Moines and Raccoon rivers, in accordance with a resolution passed January 25, 1855, by the Fifth general assembly.

\title{
October
}

I kissed her, calmly, boldly kissed my love; The leaves at this rash act, ali colors turned; The ripening corn in sun-kissed fields was shocked; The Sumach's cheek with hectic color burned!

I kissed my love; her lips by grape-juice stained;

She raised her smokey veil for my caressAbout her neck were hawthorn apples strung, And coral berries fringed her Autumn dress!

We meet but once a year, my love and I, Our trysting place, the forest; time, the fallTo love and lose October once a year Is better than to have never loved at all!

-Tac Hussey

\section{Iowa Legislator Reached 104 Years}

Another Iowa centenarian legislator has been revealed in the person of George Andrew Gordon, who represented Montgomery county in the Iowa house in the Ninth and the Ninth extra sessions, during the Civil war period, his home being at Red Oak Junction. The AnNals is indebted to Hon. Claus L. Anderson, of Stanton, for this information, who was a member of the Thirty-fifth and Thirty-sixth General assemblies. He referred the AnNals editor to the journal of proceedings of the Fortieth General Assembly, which disclosed that in $1923 \mathrm{Mr}$. Gordon had sent greetings from his home at Eureka, Kansas, where he spent his last years, to members of the Iowa house in session, and was 102 years of age at that time. He had attained 104 years upon his death there in 1925. 
Mistakenly, upon the death on October 6, 1955, of Dr. Samuel Henry Bauman, formerly a member of the Iowa house from Van Buren county, the ANNALs had characterized him as "the oldest legislator in Iowa history," and the only member of a general assembly to attain the rank of a centenarian, his 100th birthday having been celebrated the previous August 14th. Both of these statements now prove to be in error.

The house journal of March 6,1923, page 762, contains the message of $\mathrm{Mr}$. Gordon and the resolution adopted, as follows:

\section{Communication From George Andrew Gordon}

The following cummunication was received from George Andrew Gordon, a former member of this House:

George Andrew Gordon, member of the Iowa House of Representatives in 1862, sends greetings to the members of the House of 1923, now in session.

$$
\text { G. A. Gordon }
$$

Age 102, January 22, 1923.

Eureka, Kansas. February 26, 1923.

Resolution

Williams of Montgomery offered the following resolution:

Whereas, The house is in receipt of greetings from a former member of the General Assembly who had the honor of serving the state of Iowa in the Ninth regular and Ninth special sessions and who has now reached the mature age of one hundred two (102) years and now resides at Eureka, Kansas, therefore,

Be It Resolved, by the House of Representatives of the Fortieth General Assembly, That it acknowledges, with much pleasure, the greetings received from Hon. G. A. Gordon, a former representative in the legislature of Iowa, from the twelfth district comprising Montgomery county and,

Be It Further Resolved, That the house hereby extends to Mr. Gordon its most hearty congratulations upon reaching the ripe age which he has now attained and expresses the hope that he may live to add many more years thereto, and

Be It Further Resolved, That in grateful appreciation of the services rendered by him to the state in the war stricken days of 1862, the house does hereby convey to $\mathrm{Mr}$. Gordon most sincere greetings and best wishes.

Be It Further Resolved, That the Chief Clerk is hereby directed to send Mr. Gordon a certified copy of this Resolution.

Unanimous consent having been obtained for immediate consideration of the resolution, Mr. Williams moved its adoption. 
Motion prevailed and the resolution was adopted.

\section{Gordon's Lafe and Death in Kansas}

Through the courtesy of B. L. Wickstrom, editorpublisher of the Stanton Viking, the ANNALs is privileged to present the following account of the last days and death of Mr. Gordon, taken from the Eureka Herald, November 5, 1925.

The long and eventful life of Eureka's grand old man is finished at age of 104 years. George A. Gordon, Greenwood county's oldest and most distinquished citizen, died at his home in Eureka October 29 at the remarkable age of 104 years. Mr. Gordon had lived in the lifetime of every president except Washington and had voted at every presidential election in eighty-four years, except one. He had listened to Revolutionary war stories from his grandfather, George Gordon, who was a member of Washington's army in that great struggle. Mr. Gordon attributed his longevity to his temperate habits and an active outdoor life. He always has been a great reader and took an active part in political campaigns.

The attainment of an extreme old age was a matter of much satisfaction to this centenarian, because early in life he was in ill health and was compelled to give up the practice of law, upon which he was just embarking at Newton, Illinois. An overland trip to Texas in 1849, in which he had typical experiences of the wild west, such as getting caught in a buffalo stampede and being chased by Indians, so improved his health that he decided to take up farming, which was his occupation until his retirement to his home in Eureka some years ago. He is the last of a family of thirteen children of John and Ann Armstrong Gordon.

The funeral service, conducted by the Rev. Hugh Lovell, was held at the Congregational church Sunday afternoon. A male quartet, Messrs. C. C. Bailey, Ralph Marlin, Carl Betsher and Dean Marriott, sang Mr. Gordon's favorite hymns. "Come Ye Disconsolate" and "Lead Kindly Light." The Masons, of which order Mr. Gordon had long been a member, had charge of the service at Greenwood cemetery where interment was made. The following obituary and eulogy to the life of this great and good man was given by the Rev. Lovell at the funeral hour:

"George Andrew Gordon was born in Warren county, Ohio, on January 22, 1821. When God's call came during the past week he was nearly 105 years of age. It was a long life. It was a life really lived. The years were full of service, aglow with honor, and crowned with faith. 
"He was of Scotch-Irish descent. By both blood and tradition was his life buttressed. He received his education in Miami University and Wabash College. This past June Wabash College conferred upon him the degree of Bachelor of Arts. He also had been elected to membership in the order of Sons of the American Revolution.

"On September 22, 1842, he was married to Sarah Eleanor Dunn, of Crawfordsville, Indiana. To this marriage were born nine children, three sons and six daughters. Walter D. Gordon of the 23rd Iowa Infantry died July 30, 1863, of fever contracted in the siege of Vicksburg. Heustis A. Gordon of the 4th Iowa Infantry was killed in battle in Sherman's campaign against Atlanta in 1864. A son, Albert, died in his third year. The two sons who grew to adulthood were given to the cause of the Union. Mrs. Gordon died at.her home near Eureka, March 18, 1901, in her 83rd year. The daughters survive the father. They are: Mrs. E. S. Weidman, Mrs. Hypatia B. Hart, Mrs. L. F. Johnston, Miss L. M. Gordon, Mrs. E. E. Badger, and Mrs. Alice Gordon Kalb. The descendants are many, among them Gordon A. Badger, superintendent of our Sunday School.

"The deceased was admitted to the bar in 1844, but poor health compelled him to abandon that profession for outdoor life. He chose farming for his occupation. He followed it many years. He was a member of the Indiana Constitutional convention of 1850-1851, and for a number of years was the sole surviving member of that body. He has been a member of the Iowa legislature and has filled other important offices. He became a citizen of this county in 1867. He purchased a farm near Eureka (the town was not then surveyed). The years since then he has spent between the farm and Eureka itself.

"Public profession of the Christian religion was made by him in 1841, and he united with the First Presbyterian church of Crawfordville, Indiana. In 1868, he was one of the ten original members of the Congregational church of Eureka.

"On the occasion of his 100th birthday Eureka made special recognition of the day. The Glee club and band serenaded him, the church and lodges with which he was affiliated offered special congratulations. The following Sunday, a special service in his honor was held in the church. The deceased took communion with others in the fellowship.

"He was a man of culture and of strong mentality. For a generation after the Psalmist's mark of old age his mind continued keen. He was a gifted speaker and a capable lecturer. In the conventions he spoke extemporaneously and so rapidly that the stenographers could not keep pace with him. 
He was asked to write his speeches, but refused to do so on the ground that he needed the time to follow the proceedings. His mind was alert, and action always positive. The tenderness shown towards the old patriarch by those left behind, the honor and love tell of his character. Home was a mighty citadel where souls were made strong. There he loved and guided."

\section{LEGISLATOR IN INDIANA}

A Red Oak newspaper article dated Feb. 1, 1922, told of George A. Gordon, being a resident of that locality for several years around 1853, when he moved there overland from Illinois, who had what was probably the most remarkable record of any man in the United States. He likely was the only man then alive who was the grandfather of a veteran of the Civil War. Mr. Gordon later lived at Eureka, Kans., and was hale and hearty at 101 years of age. He attributed his extreme age and longevity to strict compliance with the laws of nature and the fact that he never allowed himself to worry; also he had never used tobacco or liquor in any form.

His extreme age brought $\mathrm{Mr}$. Gordon a number of distinctions. Members of his family then claimed that he was the only grandfather of a living Civil war veteran; that he was the last surviving member of the Indiana state constitutional convention of 1850 ; and one of few, if not the only man then living, who heard Revolutionary war stories from his grandfather, who took part in it.

"My grandfather, George Gordon of Cumberland, Pa., was a soldier in the American Revolution," related $\mathrm{Mr}$. Gordon. "It was my great uncle, William Armstrong, who captured the six Hessians and took them into Washington's camp, and said in reply to the general's question as to how he captured them: 'Faith, I surrounded them!' I recall as a boy hearing my grandfather tell of this and other incidents of the Revolutionary war."

Mr. Gordon united with the church in 1841, and was a Mason. He was born in Warren county, Ohio, near Springboro, January 22, 1821. He moved to Sullivan county, Ohio, in 1836, and received his education at 
Miami university and Wabash college, but left college before graduating.

He was married to Sarah Ellinore Dunn of Crawfordsville, Ind., September 22, 1842. To this union nine children were born. He lost two sons in the Civil warmembers of the Fourth and Twenty-third Iowa infantry. His children then living were Mrs. Daniel S. Wiedeman, El Dorado, Kans., Miss Laura M. Gordon, Mrs. Emma E. Badger, Mrs. Alice Kalb, all of Eureka, Kans., Mrs. Hypatia B. Hart, Seattle, Wash., and Mrs. Lizzie F. Johnson, Denver, Colo. He then had nine living grandchildren, twenty great-grandchildren and four greatgreat-grandchildren. State Senator Gordon A. Badger of Eureka, Kans., was a great-grandson.

School teaching was Mr. Gordon's first occupationat Monmouth, Ill. He studied law and in 1844 was admitted to the bar. When elected to represent Howard and Cass counties, Ind., in the constitutional convention of 1850 , he was a resident of Kokomo. In 1853 he moved to a farm near Red Oak. He was elected to the Ninth Iowa General Assembly in 1862. After the close of the Civil war, he moved near Pleasant Hill. Two years later he moved to Kansas. During his life, Mr. Gordon lived in the lifetime of every president except Washington and voted at every presidential election in eighty years except one. This publication is indebted to Claus L. Anderson of Stanton, for some of the above information. Mr. Anderson served in the Thirty-fifth and Thirtysixth General Assemblies from the same county.

\section{Iowa's Enormous Loss}

For a sparsely settled young state, with only about fifteen years of statehood, Iowa contributed over 75,000 men to the Union ramy in the Civil war, some 13,000 of whom met their deaths. Many attempts have been made to assess responsibility for this holocaust and historians still disagree. All appraisals have been inadequate in varying degree, mainly because of prejudice, eulogy or unwillingness to face facts. 
Copyright of Annals of Iowa is the property of State of Iowa, by \& through the State Historical Society of Iowa and its content may not be copied or emailed to multiple sites or posted to a listserv without the copyright holder's express written permission. However, users may print, download, or email articles for individual use. 